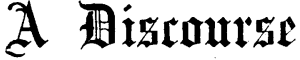

\author{
on
}

\section{MODERN PROBLEMS RELATING THE ANTIQUITY OF MAN.}

Delivered at the Meeting of the British Association For the Advascenext of Science, held at Dundee, September, 1912.

BY

ARTHLR KEITH, M.D., IL.D., F.R.C.S., heNtrria professol, rofal collegil of surgeoNs of ENGlaNd.

ON my bookshelves there is placed a series of odd volumes containing past reports of this association, which Fortune sent my way many years ago on a Whitechapel boolstall. Among them there is one volnme I prize-that which contains the history of the mecting at Aberdeen in 1859. In that volume you will find an early phase of the subject of my discourse for this evening--the Antiquity of Man. Sir Charles Lyell presided over the Section of Geology; in his opening address he announced that "a work will very shortly appear by Mr. Charles Darwin, the result of twenty years' observation and experiment," and that the evidence which had accumulated in recent years " made it probable that man was old enough to have co-existed at least with the Siberian manmotli." From other statements made in his address it is clear that Lycll was then convinced that man's appearance on earth was infinitely older than the limits fixed by Biblical record. I do not suppose I have a single listener who heard that address in Aberdeen fifty-three years ago, but even those who are not yet old will concerle that the new doctrine, even as preashed by Sir Chrrles Lyell, was not likely to be acceptable to the gerieral membership of the Gcological section in the year 1859. You will find an exact record of what happened at the meeting-not in the official report of the year, but in the letters of Mr. William Pengelly, the explorer of Kent's Carern. Orthodoxy was represented at the meeting by the Rev. Dr. Anderson, who, in Mr. Pengelly's words, "attempted to castigate Lyell for his opening address." There was a considerable amount of orthodoxy in tho room, and Dr. Anderson got a very undue share of applause. The doctrine which Lyell and his companions championed in the face of public opprobrium in 1859 is the accepted and orthodox opinion of the vast majority of thoughtful people in the year 1912.

That splendid movement of the nineteentl century which knocked the shackles of tradition from the problem of man's origin was led by men of courage, conviction, and sound judgement. It was a progressive and victorious movement they initiated, but in every movement of that lind there comes a time when those who cleared the way turn circumspect, cautious, and more crititical than constructive. Opinion tends to become fixed and conventionalized, and then a new hetercdoxy raises its head. That is the phase which we, who make a special study of the facts relating to man's origin, seem to have reached now. I cannot cite a more stalwart or distinguished representative of the orthodox opinion of to-rlay than Professor Boyd Dawkins of Manchester. In his Huxley Lecture of 1910 he gives very clearly his opinions on the antiquity of man-ripe convictions which are founded on a lifetime of active investigation and study. In his opinion, the history of man does not extend beyond the Pleistocene period - the phase of the eartl's history which immediately preceles the one in which we live. $\mathrm{He}$ accepts the fossil man of Java--Pithecanthropus-a being with a brain a little more than half the size of a modern man's, as representative of mankind at the beginning of the Pleistocene; $b$ fore the end of that period men of the modern type appeared. In Professor. Boyd Dawkins's opinion, then, mau was evolved during the Pleistocene period, and therefore, from a geologist's point of view, is a recent addition to the earth's fauna. If we ask how long ago it is since man appeared, Professor Boyd Dawkins replies:

It cannot be measured in rears-only by the sequence of geological events, and by the changes in animal life.
Yet we are certain that years came cycling round in the Pleistocene period just as they do now, and that every cycle wrought some degree of change on the face of the earth and on the form of living things-a degree of change which may be imperceptible in the period of a man's life, and yet cumulative and apparent in the course of time. Men who have studied the transformations effected during the Pleistocene period have formed varying estimates of its duration, but we may safely adopt as a moderate figure the 400,000 years given by Professor Sollas at a meeting of this association in 1900. We may accept, then, as the orthodox opinion of to-day, that the dawn of the very earliest form of humanity lies 400,000 years behind us; in that space of time man as we know him now was erolred from a crude, almost prehuman form.

For a representative of modern heterodoxy-as far as relates to the antiquity of man-we cannot do better than visit the Royal Natural History Museum in Brussels, and follow the guidance of M. Rutot, who has devoted himself to the study of the stone implements of ancient man and of recent geological formations. One civilization succeeded another in Pleistocene as in historical times. You will admit, when you examine the handiwork of the men of the Magdalenian age - at the close of the Pleistocencthat our ancestors were then artistic and skilled workmen. As we pass back wards in time from the Magdalenian to the Solutrean, and from the Solutrean to the Mousterian, Mousterian to Acheulean, and Acheulean to the Chellean-thus passing well beyond the mid-point of the Pleistocene-wo find that although the handiwork of man changes in form and in design it does not lose in skill of execution; those flints of the remote Che!lean period assure us that man had then a capable brain and a skilled hand. When, however, M. Rutot proceeds to show us the implements which wero fashioned by men in the earlier parts of the Plcistocene, it is very probable that our orthodox companions will pull out their watches and find they have pressing engagements elsewhere. Human workmanship becomes cruder as we approach the commencement of the Pleistocene. The stones which have been wrought by man's hand (eoliths) become then more difficult to distinguish from those which have been shaped by natural forces. M. Ruto however, is convinced that lic has traced man, by means of his eolithic culture, not only to the commencement of the Pleistocene, but into and through the two long geological periods which preceded the Pleistocene-the Pliocene and Miocene-and even well into the formations of the still older period, the Oligocene. In M. Rutot's opinion the origin of mankind must be assigned to a time as early as the Oligocene period. Professor Sollas has made a provisional estimate of 900,000 ycars for the Pliocene, and $1,800,000$ for the Miocene. On this crude estimate, the heterodox opinion as to the antiquity of man must bc placed at over $3,000,000$ yearg. It is only just to $M$. Rutot to state that he would by no means agree to the estimates given by Professor Sollas. In his opinion the duration of the Pleistocene period was not more than 139,000 years.

The modern heterodox movement, which I have sought to bring before you in the person of M. Rutot, had as its pioncer the late Professor Prestwich, a geologist whose long experience and great knowledge were tempered with a sound and conservative judgement. In 1859 he found fints on the uplands of Kent, between the Thames and the Weald, which he recognized as certainly the handiwork of man. Thousands of these eoliths have been collected by Mr. Benjamin Harrison. The deposits in which theso eoliths are found were assigned by Professor Prestwich to a Pliocene date. Fifty years ago Sir Charles Lyell expressed the opinion that "signs of man's existence" would be fonnd in the Cromer beds of East Anglia which mark the commencement of the Pleistocene period in England. Eoliths have been found not only in the Cromer beds, but also in the Pliocene formations of that district-in the Norwich crags by Mr. Clarke, and under the Red Crag by my friend Mr. Reid Moir. Thus in England heterodox opinion traces man to the commencement of the Pliocerc period. I need only add that eoliths, as evidence of man's existence, are rejected by many whose opinion is entitlcd to our respect. The usually accepted opinion, then, is that man makes his appearance in a definitely human form about the commencement of the Pleistocene period; there are also those who refer his evolution to a much earlier period of geological history. 
One thing is certain, whatever period is adopted, the time must be long enough to allow mankind to be distributed and differentiated as we now see it in the world of to-day. Modern human races, white and yellow, red, black or brown, although so different on the surface, are yet so similar in their structure and constitution that we must suppose all of them to have arisen from a common stock. Let us look at the problem in a concrete form. I will take as opposite and contrasted types of modern humanity the fair-haired, white-skinned, round-headed European and the woolly-haired, black-skinned negro of Central Africa, and set them side by side and study them from a purely zoological point of view. We must admit that both are highly specialized types; neither represents the ancestral form. Now, in seeking for the ancestral form of our breeds of dogs, of horses, or of cattle, we select one of a generalized and ancient type-such as we conceive might have been modified to produce modern breeds. We must apply the same system to human races. If we search the present world for the type of man who is most likely to serve as a common ancestor for both negro and European, we find the nearest approach to the object of our search in the aboriginal Australian. He is an ancient and generalized type of humanity; he is not the direct ancestor of either negro or European, but he has apparently retained to a greater degree than any other living race the characters of that common stock from which both European and negro arose. If, then, we accept the Australian native as the nearest approach to the common ancestor of modern mankind-and it must be admitted that it is not a low form of man we are postulating as a common ancestor-can we form any conception of the length of time which would be required to produce the African and the European from this common stock? What do we know of the rate at which mankind evolves? There is the classical instance of Egypt. During his residence in that country, Professor Elliot Smith and his colleagues-Dr. Wood-Jones and Dr. Derry-had opportunities of examining the remains of Egyptians belonging to every period-from pre-dynastic times to the present day. 'I'hey had thus facilities for studying the evolution of a people over a period of at least 6,000 years-probably longer. They found eridence of an infiltration of foreign blood both from the North and from the South; they noted minor alterations in the configuration of the head and in the state of the teeth and jaws, but they could not say that the men at the end of that period were in any respect a higher or more specialized type than the inhabitants of the Nile Valley at the beginning of that period. There is no need to go beyond our own country to find evidence that the evolution of man proceeds a slow rate. We have now material enough to form a fairly accurate conception of the physical condition of the people who lived in Britain these 4,000 years past. Were the prelistoric Britons to come amongst us now, dressed in our modern garb, they would pass unnoticed as fellow citizens. The neolithic men of France, Switzerland, and Germany were not in anywise a lower race than their successors of to day. When we pass to examine human remains belonging to more remote periods we are con. firmed in our belief that the evolution of human races is a slow process. In this country there have been found at Galley Hill, at Bury St. Edmunds, and at Ipswich human remains which belong at least to the middle part of the Pleistocene period. These remains indicate a kind of man somewhat different from ourselves, but yet of the same type. In size of brain and in complete adaptation to an upright posture they cannot be described as less highly evolved than we are. Such evidence as we have, then, leads us to believe that the evolution of a new and distinct variety of mankind requires an extremely long period of time.

If we again ask, How long will it take to evolve the African on the one hand and the European on the other from a common stock?-Australoid, we suppose, in formit is very apparent, on our present knowledge, we must make a very considerable allowance of time. My own opinion is that the whole length of the Pleistocenea period, we shall say, of 400,000 years -is not mole than sufficient. I am thus postulating in order to explain the differentiation and distribution of modern races; that mankind, at the beginning of the Pleistocene period, had reached a physical condition which has its best modern representation in the aborigines of Australia.

Is it not possible, however, that the evolution of man's body may not be a story of slow, continuous, almost imperceptible change, but one of alternate spurt and quiescence? The human body is notoriously the subject of sport, of defects and malformations. Many of you will recall the book which Professor Bateson published eighteen years ago, entitled Material for the Study of Variation. The work contained many facts which seemed to indicate that the animal body was subject to violent structural changes, and that a new form of being might be produced almost at a bound. We often see men in whom there is an extra vertebra in the loins, an additional rib, or a supernumerary digit, but we now recognize that these marked structural changes are merely the extreme manifestations of a normal degree of variation of which every man's body is the subject. The bodies of men and anthropoids are notoriously liable to anatomical variation, and we are justified for that reason in regarding their bodies as particularly plastic material in the hands of evolution. When, hovever, we come to examine the anatomical differences which separate one race of men from another, we see that racial character's comprise, not those marked variations which so frequently are seen by the students of human anatomy, but a multitude of minor structural features such as might slowly accumulate in the course of the differentiation of one race from another. When one comes to realize the extremely complex structure and finely adjusted nature of the liuman brain, it becomes very apparent that any addition to the most essential structure of the lumman body must be the result of an extremely slow process of growth. Only one line of evidence shakes our belief in the slow rate of human evolution, and that is the study of certain diseases of growth to which man is liable. Wo have come to realize in recent years that we are--as regards face, figure, stature, and nature-largely what our interual glands and secretions have made us. Growtl itself is definitely regulated by means of substances set free by certain glands of the body. We are absolutely certain that a marked disturbance of these glands will in the course of a few years definitely transfigure the individual to which they belong. Nature seems to have at her command a means for executing rapid advances; but when we survey what we lnow of man's past history, and mark the changes he is subject to in the present, we see no sign of her having resorted to such a means.

There is another route by which we may approach the problem of man's antiquity. Man does not stand alone; he has distant and rather despised relations-the great anthropoid apes. Although the structural hiatus between him and them is wide, yet when we compare the two types we see that there is a multitude of resemblances so intimate and so peculiar, that we cannot explain them except by supposing that man and the great anthropoids had a common ancestor at one stage of the earth's history. The great anthropoids have also a distant and primitive living relative-the gibbon. The gibbon in turn, while foreshadowing in his body the structural peculiarities of his more august relatives, finds his cousins by descent in more lowly forms still-the monkeys of the Old World and the monkeys of the new. Of these two groups the monkeys of the New World are the nearest to the original stock which gave rise to the higher primates. It was through such a lineage that man rose to reach his present estate. If, then, we are to assertain the approximate date, or, to put it in other words, the possible date at which man appeared, we must first search for the earliest traces of the basal form of the higher primates which lead towards the human line. The earliest traces we have discovered as yet were described by Dr. Max Schlosser only two years ago. Iin the very oldest Oligocene formation of the Fayoum, Egypt, the teeth and jaws of three primates were discovered. Two of these are allied to the South American apes, the other is a forerunner of the gibbons. These Fayoum fossils are of the highest importance to the solution of our problem. Their discorery assures us that at such an early date in the evolution of mammals the South American apes and the pro-gibbons were already in existence. They are highly evolved forms, and it is not unlikely that they appeared at a much earlier date. In European strata of the period following the Oligocene- 
the Miocene-many teeth and jaws of a form of gibbon' which differ only in slight and trivial details from the teeth of living gibbons, have been discovered during the past fifty years. Here, then, we have the assurance that an animal which springs closely from the stock giving rise to man has come down to us with but little change through the leagues of time marked by the Miocene, Pliocene, and Pleistocene formations. By the middle of the Miocene we know the great anthropoids were in existence; it is most unlikely that the traces we have aiscovered mark their first appearance. With the evolution of the great anthropoids the appearance of a human ancestry as a separate stock is possible. From every point of view it is most probable that the human stock became differentiated at the same time as the great anthropoids. On the evidence afforded by our very im perfect knowledge of fossil forms of apes we are justified in assuming that a very primitive form of man may have come into existence during the Miocene period; at the very latest during the early part of the Pliocene. Thus, when we pursue the question of man's antiquity by studying the forms of primates contained in the Tertiary strata, we find reason to extend the possible date of his origin at least a geological epoch beyond what is allowed by the strictly orthodox. We are unable, however, to find cvidence in support of the more extravagant claims of the ultra. heterodox represented by M. Rutot.

There is still another and a very important line of evidence bearing on the antiquity of man. We have, in the most cursory manner, followed the evolution of various ascestral forms of ape and anthropoid from the past towards the present; I propose now to follow the history of man's evolution, so far as we yet know it, from the present into the geological past. We are all evolutionists nowadays, and it is but natural that every one of us should expect man to become more anthropoid and more bruial the further we trace him into the past. What have we found? At the close of the Pleistocene period, which even orthodox and conservative geologists admit to have come to an end some 15,000 years ago, the men of Europe in stature and in size of brain were at least our equals. In tooth, limb, and bone they were more robust. Wlien, however, we turn our eyes to France and pass backwards in the Pleistocene to the milder epoch marked by the list or fourth of the cold cycles which subdivided that period, modern man disappears; his place is taken by a human being of an altogether different kind-a human race or species to which the name of Neanderthal has been given by international consent. During the last six years, thanlis to the enthusiasm, industry, and genius of French anthropologists, the remains of four individuals of this race have been unearthed. The strata in which these remains were found contain stone implements of the type known as Mousterian and of animals belonging to a cold climate. Neanderthal man appears suddenly in this later part of the Pleistocene, and as suddenly disappears, to be replaced by modern man. It is impossible to conceive that, just at the close of the Pieistocene period, Neanderthal man was suddenly converted into modern man. Think for a minute of the interpretation you would give of the Australian strata that are being laid down now. The older deposits contain the remains of aborigines; the newer, Europeans. You do not suppose that the aborigines are suddenly transformed to European. You must apply the same interpretation to the human remains found in the later Pleistocene. There was a supersession, not a transformation of races. We must infer, then, that at the end of the Pleistocene period there were two distinct races of mankind-Neanderthal and modern. That is a fact which our French colleagues secm to grasp with difficulty.

To follow the history of modern man into the past we shall return to England. It is a mystery why Neanderthal remains have not been discovered in England; they ought to be found, and a rumour is now current that they have been found. The oldest remains so far unearthed in England all belong to the modern type of man. They take us a long way further into the Pleistocene than thic era of Neanderthal man. The skull fragment, known as the Bury St. Edmunds, was found in strata containing Acheulean flints and remains of the maramoth; the $90-\mathrm{ft}$. terrace of the Thames, in which the Galley Hill man was found, contains flints of the Chellean type. The Acheulean and Chellean flint civilizations are attributed by Professor Boule - a most reliable authority - to the long temperate interval which lies between the last two of the glacial cycles of the Pleistocene, or, if we accept the evidence of Professor Penck, between the second and third cycles. If Mr. Reid Moir and I are right in regarding the human remains lately found at Ipswich as resting under a bed of undisturbed chalky boulder-clay-it is right to say that our inferences are contested-then we have carried the history of modern man a step still further back in the Pleistocene period, for the chalky boulder-clay is the product of the great cold cycle which preceded the Chellean industry. So far as the evidence in England goes, it indicates the existence of a modern type of man at least as far back as the middle of the Pleistocene period.

All we know of man in Europe near the beginning of the Pleistocene is the famous lower jaw found near Heidelberg in 1907. A complete lower jaw with its full complement of teeth can tell with certainty a great deal about the individual to which it belonged. There is not a shadow of doubt that the Heidelberg man belonged to the Neanderthal type; perhaps he may best be described as pre-Neanderthaloid, for in strength and massiveness of jaw he foreshadows the Neanderthal men whose remains are found in Europe towards the end of the Pleistocenc. Of the Neanderthal race in the middle phases of the Pleistocene we have, so far, discovered no trace. Although in many features Neanderthal man shows resemblances to the anthropoids, in other's he is highly specialized. The teeth of an Australian native make a nearer approach to the anthropoid condition than those of Neanderthal man.

Wo have knowledge of another fossil man belonging to the beginning of the Pleistocene. In 1891 Dr. Eugene Dubois discovered in Java the fossil remains of a man who in stature, posture, and gait must have been very similas. to us, but so unlike us in head form that his discoverer named this new form of man-Pithecanthropus. The size of his brain (855 c.cm.) was little more than half the size of the brain of a well-cleveloped modern man. The Neanderthal man described by Professor Boule had a cranial capacity of 1,600 or $1,625 \mathrm{c.cm}$. It is usual to accept the fossil man of Java as representative of his time and race, but if wo do we have to suppose that, in the early part of the Pleistocene, witlrin a.comparatively short space of time, the human brain developed at an astounding and almost incredible rate. I leave the matter there, simply asking my audience to keep in mind that there did exist in tho Far East at the beginning of the Pleistocenc, or perhaps close of the Pliocene, a very low form of primitive man.

Thus we have a knowledge-a very imperfect know. ledge- of only two human individuals near the beginning of the Pleistocene pericd. The one was brutal in aspect, the other certainly low in intellect. It is hard, then, to believe that in strata belonging to the period preceding the Pleistocene there could be found fossil remains of a man of quite a high and modern type. Yet the details relating to the discovery of human remains by Professor Ragazzoni in early Pliocene strata of North Italy are so circumstantial and supported that one cannot put them lightly aside. In 1860 l'rofessor Ragazzoni was searching in undisturbed Pliocene strata for fossil shells, he discovered remains of a human skull. His discovery was received with derision. Between 1860 and 1880 lie found in the same strata remains of three further indlividuals. The only living anthropological anthority, so far as I can learn, who accepts Ragazzoni's discovery as authentic is the celebirated Italian -anthropologist, Professor Sergi, of Rome. If the remains found in these strata had been of a primitive-type their authenticity would never have been called in ques. tion, but as they represented individuals as highly evolved as we are, the easiest solution of the problem was to suppose that by some means these remains had been interpolated in ancient strata at a later date.

Is it, then, possible that a human being, shaped and endowed as we are, may have existed so early as the Pliocene period? If we accept as authentic all the evidence brought forward by those who have traced man backwards by means of flints which have the appearance of man's work on them, then we must admit that Pliocene man is possible, for stones, apparently artificially fashioned, have been found in strata as old as the Eocene. If, on the other hand, we examine the evidence relating to that 
group of animals to which man belongs-the higher primates-the facts, so far as we know them, render the existence of man in the Eocene and Oligocene periods impossible, improbable in the Miocene period, but quite possible in the Pliocene. If, finally, we take into consideration all the evidence relating to fossil forms of man, we must confess that the antiquity of the modern form of man is still an open problem. I, for one, am convinced that we have followed him almost unchanged to at least the middle of the Pleistocene, when we find him accompanied by another form of man almost as distinct from him as the gorilla is from the chimpanzee. Still further back, at the beginning of the Pleistocene, we find at least two forms of men-the pre-Neanderthaloid of Heidelberg and the small-brained man of Java-but the representatives of modern man at this early period we do not know. It does seem to me, taking all the scraps of evidence at our disposal, the slow rate of human evolution, and the great blanks in the geological record into account, that a man as high as the Australoid of to-day was then in existence, but I cannot bring myself to believe that human individuals as highly evolved as those discovered by Professor Ragazzoni were in existence at an early part of the Pliocene period.

The problem of man's antiquity is not yet solved. The picture I wish to leave in your minds is that in the distant past there was not one kind but a number of very different kinds of men in existence, all of which have become extinct except that branch which has given origin to modern man. On the imperfect knowledge at present at our disposal, it seems highly probable that man as we know him now took on his human characters near the beginning of the Pliocene period. How long ago that is must be measured, as Professor Boyd Dawkins insists, by the changes which the earth and living things have undergone, and yet it is only human to try to find a means of measuring that period in a term of years, and the estimates at hand give an antiquity of at least a million and a half of years.

\section{THE \\ CHIEF USE OF THE PERITONEUM: A SUGGESTION:*}

$\mathrm{BX}$

JOHN HOWELL, M.B., B.S.Lond., F.R.C.S.Eng., HONORARY SURGEON, CHELTENHAM GENERAL HOSPITAL.

Two years ago I had the pleasure of giving you the first rough outline of my theory of the use of the peritoneum. In addition to its well-known uses as a mechanical lubricator for the efficient movement of the intestines, as a lymph sac, as a secretory and absorptive gland, I ventured to propound what I considered to be its greatest use, " that of a perienteric trap for the reception and annihilation of micro-organisms which constantly and normally-that is, without producing symptoms-permeate the intestinal wall. It is part of the duty of certain organs intimately connected with the peritoneal cavity, of which the liver, stomach, and intestines are the chief, to excrete the toxic products formed therein, including, in times of stress, the bacteria themselves, with the minimum risk of contamina tion to the remainder and more important parts of the body."

Let me recall some of the more important facts in the anatomical environment and development of the peritoneum.

The Anatomy of the Coflom.

1. The total extent of its surface equals one and a half times the surface of the skin, consisting of living secretory cells, varying in shape and size in different parts intimately connected with a most extensive subendothelial lymph capillary and blood capillary plexus, and irregular ramifying lymph spaces, yet varying in the intimacy of its attachment to the organs which it covers.

2. The visceral layer of the peritoneum forms the outer lining of the absorptive portion of the alimentary canal and its outgrowths. The internal epithelial lining of this part of the tube consists of a single layer of columnar

* Read before the Gloucestershire Branch of the British Medical Association. cells with basement membrane lying directly on submucous retiform or lymphoid tissue in direct communication, in spite of muscularis mucosae and muscular layers, with the above subendothelial lymph spaces and plexus. The "duct" portion of the tube, mouth, pharynx, and oesophagus is lined with squamous epithelium on a mucli firmer and denser rete, and has no peritoneal covering.

3. The blood and lymph circulation is in both cases enormous. It is true that the absorption of air and of focd requires a large blood supply; it is still more true that Nature makes the utmost use of her opportunities.

(a) The gastro-intestinal arteries come off the aorta; the veins return to the liver without exception.

(b) The right and left hepatic branches of the hepatic arteries are nolarger than the bronchial. The relative importance of their functions would be about the same-that is, nutritive to the framework of the organ.

(c) The omental veins also return their blood to the liver, although they have no apparent share in the absorption of nutritive material. The size of the omental blood vessels is larger than the functions hitherto ascribed to the omentum would seem to warrant.

(d) The lacteal has a blind end in the subepithelial lymphatic space of the villus; if it were simply a question of the absorption of fat globules this could be more expeditiously performed by the direct opening of a lymphatic vessel into this space, which is the case in the rest of the body. $t$ The lacteals are joined by the lymphatic sinuses around the bases of the solitary glands by vessels from the intermuscular plexuses and the subendothelial plexus connected with scores of glands in the mesentery and plexus, connected with scores of glands in the mesentery and pass to the receptaculum

The subendothelial lymphatic spaces of peritoneum and pleirra are directly continuous through the diaphragm. In the frog the peritoneal coelom communicates through stomata directly with the large dorsal lymph sac (= our perirenal and retroperitoneal lymphatic space), and thence through the lymph hearts with the systemic circulation.

The lympli from the omentum passes by way of the gastric and splenic glands to the coeliac and thence into the receptaculum chyli.

4. The movement of the lymph in the coelom and lymph spaces is insured by:

(a) The diaphragm and the intercostal muscles, the rhythmic contraction of which ceases only with life itself.

(b) The muscles of the abdominal wall. tary canal.

(d) The rhythmic contraction of the spleen.

5. Liver.-The significant histological structure:

1. Relation of portal capillaries to the liver cells.

2. Relation of liver cells to the bile capillaries.

3. The segresation of each lobule by connective tissue in direct continuation. with the subendothelial connective tissue covering the organ (Glisson's capsule).

The peritoneum covers, and is intimately connected with, almost the whole of the stomach and small intestine, liver, and spleen, and half of the pancreas (the whole in the embryo). In the stoutest person no fat has ever been discovered between the peritoneum and these organs. Appendices epiploicae are only found on the large intestinc.

6. Norve $S u p p l y$ - - Spinal sensori-motor and sympathetic nerves connect the visceral and parietal walls of tho coelom to the spinal cord. It has been found expedient to preserve a direct communication between the lungs and the stomach, liver, spleen, and the medulla; hence the vagus, the nerve of the tenth segment, has followed these organs in their downward displacement, and connects them with important centres in the lower cerebrun.

7. The Omentum.

1. Its position: It covers like an apron every viscus in the cavity except the liver, stomach, and spleen.

2. Its fimbriated edge.

3. Its power of " movement."

4. Its disproportionate blood and lymph supply.

5. Its normal coating of two or three layers of leucocytes. Associated with this is its exemption from suppuration when it has been replaced after being herniated through a wound

6. Its history: Found in mammalia and lower vertebrata grows faster than other abdominal contents during life; before 45 above pubic spine, after that below it; left border lower than right.

The benefits which the human organism has been supposed hitherto to have derived from the existenco of this organ are mechanical, and are, in my opinion,

I am aware that Cuneo in his recent work thinks that all the Iymphatic vessels are closec 